\title{
The Ethnomusicologist and the Transmission of Tradition
}

\section{Citation}

Shelemay, Kay Kaufman. 1996. The ethnomusicologist and the transmission of tradition. Journal of Musicology 14(1): 35-51.

\section{Published Version}

http://dx.doi.org/10.1525/jm.1996.14.1.03a00020

\section{Permanent link}

http://nrs.harvard.edu/urn-3:HUL.InstRepos:3292406

\section{Terms of Use}

This article was downloaded from Harvard University's DASH repository, and is made available under the terms and conditions applicable to Other Posted Material, as set forth at http:// nrs.harvard.edu/urn-3:HUL.InstRepos:dash.current.terms-of-use\#LAA

\section{Share Your Story}

The Harvard community has made this article openly available.

Please share how this access benefits you. Submit a story.

Accessibility 
The Ethnomusicologist and the Transmission of Tradition

Author(s): Kay Kaufman Shelemay

Source: The Journal of Musicology, Vol. 14, No. 1 (Winter, 1996), pp. 35-51

Published by: University of California Press

Stable URL: http://www.jstor.org/stable/763956

Accessed: 24/08/2009 21:09

Your use of the JSTOR archive indicates your acceptance of JSTOR's Terms and Conditions of Use, available at http://www.jstor.org/page/info/about/policies/terms.jsp. JSTOR's Terms and Conditions of Use provides, in part, that unless you have obtained prior permission, you may not download an entire issue of a journal or multiple copies of articles, and you may use content in the JSTOR archive only for your personal, non-commercial use.

Please contact the publisher regarding any further use of this work. Publisher contact information may be obtained at http://www.jstor.org/action/showPublisher?publisherCode=ucal.

Each copy of any part of a JSTOR transmission must contain the same copyright notice that appears on the screen or printed page of such transmission.

JSTOR is a not-for-profit organization founded in 1995 to build trusted digital archives for scholarship. We work with the scholarly community to preserve their work and the materials they rely upon, and to build a common research platform that promotes the discovery and use of these resources. For more information about JSTOR, please contact support@ jstor.org. 


\title{
The Ethnomusicologist and the Transmission of Tradition*
}

\author{
KAY KAUFMAN SHELEMAY
}

"However else they may identify themselves and each other, fieldworker and subject are first and foremost human beings. It is this shared identity that makes fieldwork, with both its problems and its accomplishments, a meaningful mode of mutual learning."

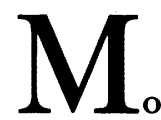

ost ethnomusicological discussions of the

transmission of tradition attempt to document and interpret the manner in which music is communicated over time within a particular setting, giving attention to both the interpersonal dynamics and communication technologies of these processes. ${ }^{2}$ However, I will focus my inquiry neither on the native carriers of tradition nor on the materials these traditions convey. Rather, I propose to take a reflexive turn and to discuss the role of the ethnomusicologist who, while seeking to document the transmission process, becomes a part of it.

Volume XIV • Number $1 \bullet$ Winter 1996

The Journal of Musicology $\odot 1996$ by the Regents of the University of California

* The initial version of this paper, titled "Intersections of Life and Scholarship: Human Relations in the Field," was delivered as part of a Colloquium Series on Fieldwork in Contemporary Ethnomusicology at Brown University in 1992. The paper was written during a 1991-1992 fellowship year funded by the National Endowment for the Humanities.

' R. A. Georges and M. O. Jones. People Studying People. The Human Element in Fieldwork (Berkeley, 1980), 3.

2 In one sense, the "transmission of tradition" is a tautology, since the etymology of the word, from the Latin traditum, refers to anything that is transmitted or handed down from the past to the present (Edward Shils, Tradition [Chicago, 1981], 12). By "musical transmission" I refer to any communication of musical materials from one person to another, whether in oral, aural, or written forms, without regard to the time depth of the materials transmitted. But for the sake of discussion here, I will focus primarily on the role of live musical performance in this process, and secondarily on musical materials mediated and conveyed by technologies such as the LP, cassette, or compact disc. 
I will approach this subject by drawing upon instances from my own field experiences and those recounted by colleagues in the literature. I wish to move discussion beyond an appreciation of the impact of "relational knowledge" 3 on ethnographic interpretation and writing to explore more deeply a type of reciprocity and grounded action that is a surprisingly frequent outgrowth of the ethnomusicological research progress. I will suggest that an idiosyncratic theoretical stance and working methodology give rise to this outgrowth of ethnomusicological research and that it likely has its roots in the close but conflicted relationship of ethnomusicology with other disciplines.

It is necessary to sketch a brief disciplinary perspective, to which I will return again later in this essay. In terms of its intellectual history and the training of its researchers, ethnomusicology has been shaped by the often contradictory worlds of historical musicology and anthropology. For the historical musicologist, the transmission of tradition is such an implicit aspect of her activity that it has largely escaped critical scrutiny. Any card-carrying historical musicologist would readily acknowledge that she is implicated in the continuation of the tradition studied. From its inception, historical musicology has had as an important adjunct to its scholarly mission the (re)discovery, interpretation, and perpetuation of musics of the Euro-American art music tradition. Indeed, the American Musicological Society each year presents the Noah Greenberg award "to stimulate active cooperation between scholars and performers by recognizing and fostering outstanding contributions to historically aware performance and to the study of historical performing practices." 4 The annual conferences of the Society feature special recitals and concerts of compositions not otherwise widely heard and performed.5 Thus musical manuscripts surviving only in scattered archives have been unearthed, reconstructed, edited, and performed by historical musicologists as a matter of course. To quote Joseph Kerman's appraisal of musical scholarship in Contemplating Music, "any scholarly edition of music is an invitation to a performer, and musicologists have been known to press such invitations quite

3 Anthropologist Renato Rosaldo has suggested that "relational knowledge" constitutes a shared expressive form on the "borderland" between ethnographer and 'subject,' and "should be regarded not as analytically empty transitional zones but as sites of creative cultural production that require investigation." (Renato Rosaldo, Culture and Truth. The Remaking of Social Analysis [Boston, 1989], 208)

4 American Musicological Society Directory (Philadelphia, 1993), 7.

5 Even such prosaic forums as business meetings can celebrate the re-entry of a composition into the repertory. The 1993 annual meeting of the AMS featured the first performance of a recently edited and published chamber work by Ruth Crawford (Seeger). (Judith Tick, ed., A Suite for Four Strings and Piano [Madison, WI, 1993]) Editor Tick describes herself as a type of 'musicological midwife' in the rebirth of this composition, which she was thrilled "to send out into the world." (Judith Tick, personal communication.) 
hard, lobbying, consulting, and masterminding ... concerts when they are given a chance. ${ }^{n} 6$

Indeed, the central polemic among historical musicologists vis-à-vis the act of performance and their own role in transmitting (and even reinventing) tradition seems to center largely around issues of authenticity versus creativity in the act of musical reconstruction and performance practice. 7 Musicologists do not generally question whether they should be active in the process of transmitting musical tradition; rather they simply debate how closely they should adhere to historical precedent and in what manner the questions arising from lacunae in their sources can or should be answered. Most ethnomusicologists have been trained as undergraduates in music departments subscribing to this philosophy, the same venue in which the vast majority of ethnomusicology professors eventually find their institutional homes.

This long-standing interaction between scholarly documentation and the act of performance has had its influence upon ethnomusicological theory, most notably in the notion of "bimusicality" advanced by Mantle Hood. The founder of the first major ethnomusicology program at UCLA, Hood felt that "the training of ears, eyes, hands and voice and fluency gained in these skills assure a real comprehension of theoretical studies." 8 Hood was secondarily concerned that training and performance in Western music constrained ethnomusicologists studying other traditions. However, Hood did not just write about the importance of becoming bimusical (or multi-musical) and gaining cross-cultural musical experience through performance. He established an ethnomusicology curriculum including native performers, who were brought to UCLA to instruct students in a range of musical traditions. Early Hood students went on to found other programs at Wesleyan, Michigan, Seattle, and elsewhere. Becoming bimusical became an increasingly common norm among ethnomusicologists, who capitalized upon their bimusicality by carrying out truly participatory participant-observation in the field.

6 (Cambridge, MA, 1985), 185.

7 For a rare, explicit critique of the search for authenticity in musicologicallyinspired performance, see Richard Taruskin, "On Letting the Music Speak for Itself: Some Reflections on Musicology and Performance," The Journal of Musicology I (1982), 338-49. Taruskin comes close to acknowledging the role of the musicologist in the transmission of tradition in his comments upon a story credited to Dmitri Shostakovich: "'What's a musicologist? I'll tell you. Our cook, Pasha, prepared the scrambled eggs for us and we are eating them. Now imagine a person who did not cook the eggs and does not eat them, but talks about them-that is a musicologist." Well, we're eating them now, and even cook up a few on occasions as when we do a little discreet composing to make a fragmentary piece performable. ... (Taruskin, "On Letting the Music Speak," 349.) That discourse about authenticity in editions intended for performance raises lively issues can be seen in Frederick Neumann, "Improper Appoggiaturas in the Neue Mozart Ausgabe, Journal of Musicology X (1992), 505-21.

8 Mantle Hood, "The Challenge of 'Bi-Musicality,' " Ethnomusicology IV (1960), 55. 
If historical musicology presented the ethnomusicologist with a lively model for transmitting the tradition studied, anthropology set forth a very different code of noninterference. In a series of statements on ethics by the major anthropological associations, beginning with the Society for Applied Anthropology in 1949, anthropologists are urged to aspire to responsible behavior and to avoid any negative outcome.9 Participation in and transmission of tradition is not explicitly discussed or prohibited in any of these statements, although implicitly negative attitudes toward the same can be extracted indirectly and in general terms. Only the most recent revision of the American Anthropological Association Principles of Professional Responsibility (1990) strengthens and personalizes the statement of responsibility to the "people whose lives and cultures anthropologists study," mentioning for the first time the possibility of both the "positive and negative consequences of their activities and the publications resulting from these activities". ${ }^{\circ}$ For the first time, too, the anthropologist is called upon to "reciprocate in appropriate ways" the help and services they receive in the field." While anthropologists have always been deeply involved as individuals in their respective field sites, it appears that open discussion of the potential impact of their involvement on a personal and interactional level has surfaced only within the last decade, as the former "subject" has been increasingly acknowledged as an empowered partner in the research process. ${ }^{12}$

In fact, like their colleagues trained within music departments, anthropologically-trained ethnomusicologists of recent years have actively participated in musical performance in the field, most often to ensure reciprocity and/or to test their understanding of musical data they have gathered. To cite an example from an ethnomusicological study carried out by a scholar trained primarily in anthropology, Steven Feld allowed himself to be represented as a "song man" within his own culture to the Kaluli of Papua, New Guinea, for whom he played recordings of Charlie Parker;13 Feld also composed and performed Kaluli songs for his research associates to test hypotheses about "constraints upon form." 14

9 Carolyn Fluehr-Lobban, Ethics and the Profession of Anthropology, (Philadelphia, 1991), 240-42. Ethical guidelines or codes of ethics adopted by various American anthropological societies since 1949 are printed together for the first time in FluehrLobban, Ethics, $237-69$.

10 Fluehr-Lobban, Ethics, 274-75.

11 Fluehr-Lobban, Ethics, 275.

12 Fluehr-Lobban, Ethics, 232.

13 Steven Feld, Sound and Sentiment. Birds, Weeping, Poetics, and Song in Kaluli Expression, 2nd. ed. (Philadelphia, [1982] 1988), 11.

14 Feld, Sound and Sentiment, 13. 
It is also clear that anthropologically-trained ethnomusicologists have also been influenced by Hood's maxim. In a study advocating a "musical anthropology," Anthony Seeger moves somewhat beyond Feld in incorporating musical performance for heuristic purposes. Seeger dedicates his book Why Suya Sing ${ }^{15}$ "in memory of the songs we sang," and describes in some detail the folk music styles ranging from bluegrass to African songs that he and Judy Seeger taught to the Suya; in some cases, Seeger acknowledges that he altered folksongs learned from his uncle, Pete Seeger, "to fit a pattern easily recognizable to the Suya. ${ }^{16}$ In honoring a request by the Suya that he collaborate in publishing a recording of their music, ${ }^{17}$ Seeger's activities in fact come very close to the sort of ethnomusicological participation in the transmission of tradition I seek to examine here.

Thus ethnomusicological activity in the transmission of tradition appears to draw on longtime musicological commitments to the preservation of musical tradition. Equally strong anthropological mandates against any involvement that might be perceived as interference in the tradition studied-only recently re-evaluated in the light of growing concerns regarding reciprocity and social responsibility-have rendered ethnomusicologists largely silent about their active roles both during and after fieldwork. Apart from the disciplinary implications and the insight they provide into the values of different fields of study, discussion of the role of the ethnomusicologist in the transmission of tradition lays bare an aspect of the intensely human nature of fieldwork and raises at the same time slippery issues in the ethics of ethnographic research that have been little discussed. ${ }^{8}$ Most discussions of ethics have tended to focus on interpersonal relations during and after fieldwork, and only incidentally to address the impact on the musical tradition itself.

\section{Ethnography and Transmission}

My concern with this subject did not emerge initially on a theoretical level. Rather, an experience in the field several years ago pushed me toward a new set of considerations concerning the

15 Anthony Seeger, Why Suya Sing. A Musical Anthology of an Amazonian People, (Cambridge, 1987).

${ }_{16}$ Seeger, Why Suya Sing, 20.

17 Seeger, Why Suya Sing, 23-24, in reference to the record and notes issued by Anthony Seeger and A Communidade Suyá as "Música Indígena: A Arte Vocal dos Suyá," (São João del Rei, 1982).

${ }_{18}$ Mark Slobin has pointed out that ethical issues were not discussed at all in the ethnomusicological literature until the 197os, and that ethical awareness in the field remains in an "embryonic state." (Slobin, "Ethical Issues" in Ethnomusicology. An Introduction, ed. Helen Myers [New York and London, 1992], 331.) Slobin's discussion, however, does not move beyond "the bounds of problems raised by the earlier modes of inquiry." (Slobin, "Ethical Issues," 332.) 
role of the ethnomusicologist. Let me describe in some detail the ethnographic event, and its broader context, that served to throw this consideration into relief.

For nearly a decade I have been doing fieldwork with Jews of Syrian descent who live in Brooklyn, New York. The project began as a team effort between my New York University graduate seminar in ethnomusicology and members of the Syrian community. ${ }^{19}$ I have continued research on my own since concluding the team project in 1986 and expanded its boundaries to incorporate multilocale fieldwork among Syrian Jews in Mexico and Israel. ${ }^{20}$

Some background is needed to frame the following discussion. More than seventy years after their immigration from Aleppo to the New World, a community of more than 3o,ooo Syrian Jews in the New York metropolitan area sustains a strong Judaeo-Arabic identity expressed, in part, through many aspects of musical performance. The central musical repertory is a corpus of paraliturgical hymns called pizmonim (sing. pizmon), which have newly composed Hebrew texts set to borrowed Arabic melodies. ${ }^{21}$ The pizmon tunes are adopted from popular songs in the Arabic musical tradition, while the Hebrew texts contain biblical and liturgical allusions, as well as veiled references to individual members of the community for whom the songs are composed and to whom they are dedicated. The multivocality of the songs and the memories sustained in separate channels of text and tune provide wonderful material for social and historical analysis, but that is not my subject here. The focus of the original research project on the pizmonim emerged directly from suggestions of knowledgeable Syrian community members who wanted to record as many of the extant songs as possible. The initial team research project recorded performances of nearly two hundred pizmonim and deposited copies of all in a community archive, which members of the research team also helped to catalogue and organize.

The event that highlighted issues concerning transmission took place in the Syrian community on 14 March 1990; it was a concert mounted to honor Meyer "Mickey" Kairey, a man who for many years has been a mainstay in the Syrian community's religious life. One of Mickey Kairey's most notable activities has been the teaching of piz-

19 For details about the genesis, organization, and outcome of this project, which I initiated in 1984 for pedagogical purposes within the New York University ethnomusicology program, see Kay Kaufman Shelemay, "Together in the Field: Team Research Among Syrian Jews in Brooklyn, New York," Ethnomusicology XXXII (1988), 369-84.

20 I am grateful to the Republic New York Corporation and to the Memorial Foundation for Jewish Culture for grants that supported field research in these locales.

21 More than five hundred pizmonim are published by the Syrian community in the fifth edition of a volume titled Sheer Ushbahah Hallel Ve-Zimrah (New York, 1988). 
monim to Syrian young people. Mickey Kairey played an important role as one of the chief research associates for the pizmon project and on many occasions shared his expertise with members of the research team. 22

The concert, attended by an overflow crowd of approximately three-hundred-fifty people, was held at the Sephardic Community Center in Brooklyn, the institutional center of the Syrian Jewish community. The program (see Figure 1$)^{23}$ included two different "sets" of pizmonim sung by a choir of young boys accompanied by an ensemble of Middle Eastern instruments; a third group of solo songs was performed by Isaac Cabasso, Mickey's uncle and himself a beloved lay cantor. The climax of the evening was the presentation of an oversized framed certificate to Mickey containing the signatures of some 1000 of his students trained between 1955 and 1990.

Midway through the program, there was an audio-visual presentation celebrating Mickey's life and work. Slides traced Mickey's career, including pictures of his synagogue and of his pizmon teacher and mentor, Eliyahu Menaged. There were images of Mickey's family, photos from his years of military service during World War II, and innumerable references to his love of music of all kinds, including Stan Kenton and the Big Bands of the 1940s. Slides showing Mickey training young boys for their Bar Mitzvahs were accompanied by commentary and recordings made by students during these lessons. ${ }^{24}$ Suddenly, I heard a recording of my own voice asking Mickey a question about a pizmon; it had obviously been taken from the tape of a research session we had held some five years earlier when Mickey taught pizmonim to me and my students. I was startled to find myself incorporated in this manner, to be publicly included in the experience of Mickey and his community. ${ }^{25}$

If I had any doubts that the ethnomusicologist had become a factor in the transmission of tradition among Syrian Jews in Brooklyn, they were resolved quite coincidentally during an interview that took place a

22 I also worked closely with and interviewed Mickey's brother, Hyman Kaire (the two brothers spell their last names differently), and his late sister, Sophie Cohen.

23 The cover of the program booklet contains symbols of Mickey Kairey's active musical role in liturgical and life cycle events. Alert readers will note that the table of contents contains the inscription "Happy Chanukah" at the bottom. The concert, originally planned to coincide with the Chanukah holiday in December, was postponed to the March Purim observance owing to a family emergency.

${ }^{24}$ See Figure 2 for examples of congratulations placed in the concert program by families grateful for Mickey Kairey's role in transmitting pizmonim.

25 The individual who had prepared the commentary accompanying the slide show later told me that she also had included my own singing of a pizmon on the tape, just like those of the young boys Mickey trained, but later deleted the excerpt in fear that it would offend more traditional members of the community who adhered to religious prohibitions concerning the hearing of a woman's voice. 
FiguRE 1. Program for Pizmon Concert in honor of Meyer "Mickey" Kairey 14 March 1990, Sephardic Community Center, Brooklyn, New York.
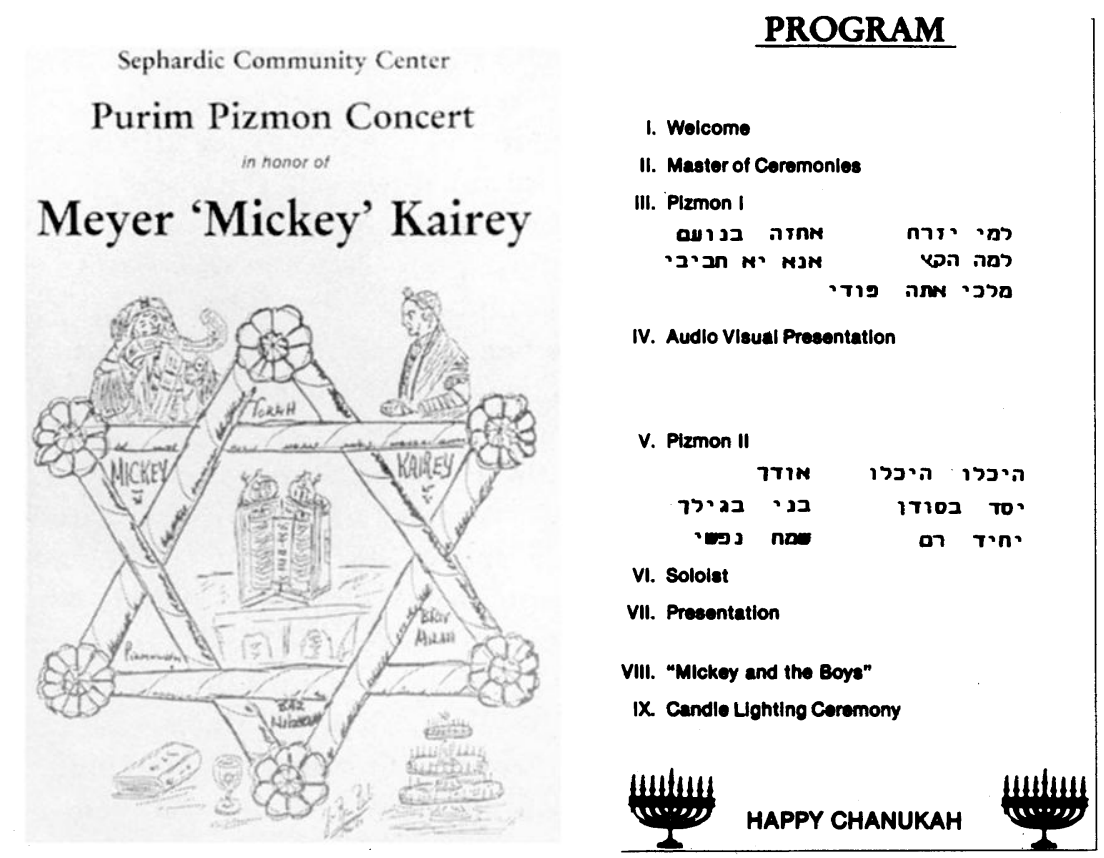

few days after the concert. The young Syrian cantor whom I interviewed discussed a revival of pizmon singing he believed to be present among young people in the Syrian community. He suggested that a catalyst was events like the recent concert, a performance genre that had emerged in the wake of the team project. ${ }^{26}$ Clearly, the Syrian music project had left more of a trace than recordings of music and oral histories in an archive. Six years after its inception, it had been absorbed into the fabric of both community activities and individual memories. The project had given rise to institutional relationships (such as that established between the Sephardic Community Center and New York University in terms of copyright and royalty agreements for a record we coproduced) 27 and a complex network of close individual friendships between myself, members of the research team, and some two dozen individuals within the Syrian-Jewish community.

${ }_{26}$ Interview with B. Zalta, 16 March 1991.

${ }_{27}$ Pizmon. Syrian-Jewish Religious and Social Song, eds. Kay Kaufman Shelemay and Sarah Weiss (Hohokus, NJ, 1985). 
FIGURE 2. Tributes from Dedication Booklet for Meyer "Mickey" Kairey, 14 March 1990, Sephardic Community Center, Brooklyn, New York.

IN HONOR OF

OUR BELOVED PIZMONIM TEACHER

MEYER “MICKEY” KAIREY

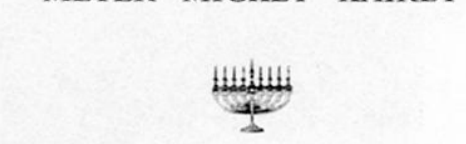

The Graduating Class

of 1970

\section{Magen David Yeshivah \\ שיר ושבה הליל וזמרה}

\section{DEAR MICKEY,}

\begin{abstract}
Just wanted to thank you for teaching us Ta'amim and Pizmonim, and tor preparing us for our Bar-Mitzvahs. Wo sing the Pizmonim every Shabbat, and now our children are beginning to pick up the tunes.
\end{abstract}

You should be very proud that our great traditions are being carried out throughout the conmunity due to your tireless efforts.

Sincerely,

gack and Bert Hidary

Reviewing my journal, project correspondence, and other residue of our long association, I found other instances of my own activity that directly touched upon the processes, personnel, and politics of transmission. Let me briefly set forth a few examples.

In June 1986, I was asked to write to the United States Immigration Service on behalf of a visiting cantor from Israel whom the largest Syrian synagogue in Brooklyn wished to retain on a permanent basis. Here I invoked my authority as a professor and used my knowledge of the tradition to aid the community in a matter of great importance to them. In fact, as an ethnomusicologist, I was actually quite concerned about this turn of events, since the distinctive Aleppo musical tradition sustained in Brooklyn was under pressure and undergoing a significant amount of change precisely because of the influx of talented Israeliborn cantors who carried different streams of Sephardic tradition. In my letter, I purposely omitted this information and consciously played a role directly affecting transmission in a direction about which I personally was ambivalent but that the community desired.

In 1987 , I was asked by a leader of the community to give him information that would help defuse a growing concern among local rabbis that so many of the melodies used in Syrian pizmonim are of secular 
and/or even of Christian or Islamic origin. Specifically at issue was the pizmon Mifalot Elohim, which borrows the melody of the well-known Christmas carol Oh Tannenbaum. It is almost certain that rabbinical skepticism had been provoked in part by the publication of our recording two years earlier and the subsequent high profile of our collaboration in what had become known as "the Syrian music project." In response to this request, I wrote a letter giving my associate information on several controversial, borrowed melodies, and provided a rationale that could be used in justifying the tradition:

I do not think the original sources of these melodies should be of any concern to you or the community. There is a long-standing tradition in Jewish music (both sacred and secular) of borrowing melodies from the surrounding society. This tradition is as widespread in Ashkenazic circles as in your own pizmon tradition, only the sources of the melodies differ because of the different geographical settings. Music is always part of the surrounding cultural milieu and I know of no tradition that is "pure" and does not borrow a variety of things with which it is in contact. The very nature of musical expression is that it is transmitted from person to person across geographic, social, and cultural boundaries. ${ }^{28}$

In this case, then, I explained the transmission process in order to justify, and ultimately, to help preserve the tradition.

The publication of the record Pizmon, which included a selection of pizmonim taken from recordings made during the first year of our joint project, had other unanticipated outcomes as well.29 The record was selected by the American Folklife Center for its annual list of recordings $3^{\circ}$ and won a prize from the national association of Jewish community centers. $3^{2}$ Both awards were a particular source of pride for everyone involved. However, the publication of the record, and the "first annual pizmon concert" mounted around the same time in 1985 , raised perceptions outside the community that the Syrian men who had come together for "music sessions" comprised a "group." 32

${ }^{28}$ Excerpt of letter from Kay Kaufman Shelemay to a leader of the Syrian community in Brooklyn (9 June 1987 ).

29 This in contrast to its planning and execution, which were quite straightforward and largely without complications. All the performers signed consent forms and the royalties (of which, in the end, there were none!) were to be divided between the Sephardic Archive and New York University. Assignment of royalties to the performers was an option rejected by the participants, since they were for the most part affluent musical amateurs for whom the receipt of money would have been highly unacceptable.

3o American Folk Music and Folklore Recordings 1985. A Selected List. American Folklife Center, Library of Congress (Washington, DC, 1985).

31 "Award for Excellence in Communications," Jewish Welfare Board Communications Competition, 1988.

${ }^{2}$ This is a surprisingly common phenomenon, the development of what has been termed new "performance frames" growing out of the impact of ethnomusicological 
My interaction with these individuals outside formal recording and interview sessions increased as we began to get invitations from area cultural institutions and universities: generally, the Syrian men were asked to perform, and I was asked to give a lecture or long introduction that "explained" the music. The men with whom I worked were quite comfortable with this arrangement despite the obvious asymmetries; indeed, they had invited me to speak at the first pizmon concert and suggested to the sponsor that I participate when they received the first invitation to perform outside the community.

I now realize that this was only the beginning of my increasingly active role in the transmission process, one that paralleled the deepening friendships between myself and members of several Syrian families. A pivotal event took place on 15 November 1987 , when the men were invited to perform a combined lecture/concert at a community center on the Lower East Side of Manhattan. As I led off the session with a talk explaining the Syrian musical tradition, the elderly audience comprised largely of Jewish immigrants of Eastern European descent got very restless. Every time I mentioned the connection of the Syrian-Jewish tradition to Arabic music and used the word "Arabic," members of the audience hissed.s3 After several such incidents, Moses Tawil, the leader of the Syrian men who were to sing pizmonim, stood up from where he sat behind me on stage and joined me at the microphone: "We are businessmen and we don't have to be here," he said emphatically. "We are interested in what Professor Kay has to say and want to hear it. Please be quiet."

I can't say that Tawil's admonition improved the audience's deportment-I still consider this talk the worst single public lecture experience I have ever had-but it was an enormously important moment of warmth and bonding between myself and the Syrian men present. From that moment forward, I received invitations to family events, Bar Mitzvahs, wedding anniversaries, and holiday celebrations. And the closer we became, the more I was called upon to play a role in perpetuating the tradition.

Thus I would like to argue that as ethnomusicologists become engaged in research with living musical traditions and the people who

fieldwork. See Daniel Sheehy, "A Few Notions about Philosophy and Strategy in Ethnomusicology," Ethnomusicology XXXVI (1992), 332. Also, Doris Dyen, "New Directions in Sacred Harp Singing," in Folk Music and Modern Sound, eds. William Ferris and Mary L. Hart [Jackson, MI, 1982], 73-79, for a detailed case study of this phenomenon in the sacred harp tradition.

33 The Arabic musical tradition is generally unfamiliar to Jews living outside of the Middle East and, for some, including members of this particular audience, evidently carries negative associations stemming from the Arab-Israeli conflict. This attitude contrasts markedly with the great pride in and nuanced understanding of Arabic music that characterizes many members of the Syrian-Jewish community. 
carry them, they both intentionally and unwittingly become caught up in the processes and politics of transmission of tradition. Sometimes their interventions support continuity, at other times they engender change. I believe that these interactions are conceptualized not as formal, scholarly acts, but are carried out relatively unconsciously on a much more personal level as the study of tradition shifts almost imperceptibly to occupy a relational space situated between scholarship and life. As relationships "in the field" mature from the initial formality of scholar/informant (if indeed there is the luxury of ample time and access) to more collegial and personal ones, the fieldworker inevitably moves beyond the management of cultural capital into the negotiation of human relations in the field.

\section{Transmission and Tradition}

As I began to reconsider what in retrospect appears to be my surprisingly active role in the transmission processes within the Syrian community, I reviewed my other past fieldwork projectsmultiple urban and rural research projects in Ethiopia, a combined archival/ethnographic experience at an American synagogue in Houston, a notably unsuccessful six-month experience with a new music group in New York City-and looked for similar patterns. Indeed, they were there, and I can only conclude that such involvement is much more prevalent than ethnomusicologists generally acknowledge. Below, I would like to identify and briefly discuss three ways in which the fieldworker is most frequently implicated in the processes of transmission. No doubt there are more, and any one ethnographic experience might give rise to varying combinations of the three at one time. As part of the process of definition, I will set forth some brief examples from my own experience and those gleaned from the ethnomusicological literature. Almost without exception, these situations inevitably arise at the point of intersection of life and scholarship-they begin at moments when the study of a tradition becomes part of the life of the tradition itself and relationships in the field deepen to a more interactional model. The three aspects include:

-Preserving Tradition

- Memorializing Tradition

-Mediating Tradition

\section{Preserving Tradition}

If any aspect of the ethnomusicologist's entry into the transmission process is generally acknowledged, it is the presumption that ethnomusicological activity works on one level to preserve. While the ethic of preservation was long an unquestioned part of the ethnographic process, 
and older paradigms led earlier scholars to seek out and study certain traditions since they would otherwise "be lost," it seems clear that the very process of studying any musical tradition is tantamount to participating in an act of preservation.

Frequently the role of the ethnomusicologist as preserver of tradition is acknowledged or even desired by people within the tradition itself. To take but one example from the literature, Barbara Smith recounts how she learned bon-dance drumming among Japanese immigrants to Hawaii, became a member of a club, and "beat the drum" at bon dances one summer. $34 \mathrm{~A}$ few days after the second bon dance at which she performed, she was told that a member of the community had commented: "Now it is safe for us to die, because if Professor Smith is drumming there will always be someone to drum for our souls." ${ }_{35}$ Smith goes on to relate that her drumming encouraged some young people to learn to play and that there has not been a shortage of drummers since.

There are most certainly instances where the ostensible "informant" charges the "ethnomusicologist" with the responsibility of transmitting tradition. A graphic example occurred in my own work in northern Ethiopia among the Beta Israel (Falasha). One day, an elderly Beta Israel priest looked at me solemnly and said: "In twenty-five years, only you will know our prayers. ${ }^{36} \mathrm{He}$ was both acknowledging a reality of the transmission process within his own community and making me aware of my responsibility to preserve his tradition.

It strikes me that preservation is therefore not just an outgrowth of older scholarly paradigms, but at least in some circumstances, both an acknowledgment of the realities of musical change as well as part of an implicit contract between the ethnomusicologist and the tradition's native carriers. This contract may be particularly crucial in the case of "insider" research, when the scholar shares, entirely or in part, the identity of the tradition's carriers.

The bon-dance drumming example cited above also highlights a type of preservation I have not personally experienced,37 but that is most common in the field at large. While all ethnomusicologists transmit "speeched knowledge" 38 and recorded music, many further transmit musical tradition through re-creating the act of performance itself. In

34 Barbara Barnard Smith, "Variability, Change, and the Learning of Music," Ethnomusicology XXXI (1987), 211.

35 Smith, "Variability," 211.

${ }^{6} 6$ Kay Kaufman Shelemay, Music, Ritual, and Falasha History (East Lansing, MI, 1989), xviii.

37 Largely because I have been a woman studying liturgical or paraliturgical musical traditions transmitted only by men, whether in Ethiopia or Brooklyn, my own opportunities for performance in the field have necessarily been limited.

$3^{8}$ See Charles Seeger, "Speech, Music, and Speech about Music," Studies in Musicology 1935-1975 (Berkeley, 1977), 16-30. 
this manner, the performative nature of the ethnomusicologist's unit of study lends itself to replication, both during and after the ethnographic research period. Many ethnomusicologists today teach at home the music they learned in the field. Although one might question this activity as an act of appropriation, I believe that it is not generally regarded as such by the native carriers of the tradition nor by the ethnomusicologist. Rather, it can be viewed as part of the very human process of passing on a world of expression that is inordinately personal. How can one read John Miller Chernoff's description of his acquisition of Ghanaian drumming techniques 39 and not acknowledge that he, like his teacher, sustains this music as "a bodily memory?" 40 Theories such as Mantle Hood's "bimusicality" allow for much more than an entry into musical learning: they implicitly move the ethnomusicologist toward the preservation, replication, and active transmission of tradition. $\mathbf{4}^{1}$

\section{Memorializing Tradition}

While we tend to conceptualize transmission in terms that are communal and social, in fact the workings of the process are intensely personal and idiosyncratic, the source of the tradition being a teacher (the informant, or more appropriately, the research associate), the receiver, a student (the ethnomusicologist). The tendency of ethnomusicologists to extrapolate from the individual to the group, combined with longtime anthropological traditions supporting anonymity for subjects of research, has resulted in fewer traces of memorializing in the ethnomusicological literature. But there are examples. Bruno Nettl has written an ode to his favorite teachers, where he discusses and memorializes the men who once would have been called his informants.42

39 See John Miller Chernoff's account (in African Rhythm and African Sensibility, [Chicago, 1979], 104) of studying drumming with Alhaji Ibrahim Abdulai, who remarked that "teaching with the hand is more than the teaching with the mouth."

40 See Paul Connerton (How Societies Remember, [Cambridge, 1989], 102) for a discussion of the manner in which physically incorporating practices "provide a particularly effective system of mnemonics."

4' Hood, "The Challenge of 'Bi-Musicality.' " Long before the notion of bimusicality encouraged performance by ethnomusicologists and sparked revivals, fieldworkers had actively intervened in the transmission of tradition. A notable example is that of John Lomax, whose early studies of cowboy songs and frontier ballads "aimed to feed back song lore into the stream of oral tradition." (Alan Lomax and Joshua Berrett, "Introduction," in Cowboy Songs and Other Frontier Ballads, ed. J. A. Lomax and Alan Lomax [New York, 1986], xi, cited in Sheehy, "A Few Notions," 326.)

$4^{2}$ Bruno Nettl, "In Honor of Our Principal Teachers." Ethnomusicology XXVIII $(1984), 173-85$. I would note that the most striking examples of preserving, memorializing, and mediating tradition have been recounted initially in the oral tradition of the field, i.e., in lectures only later published. This is true of Nettl, "In Honor," and Smith, "Variability," both of which were first presented as Charles Seeger Lectures at annual meetings of the Society for Ethnomusicology. 
Likewise, the autobiography of Frank Mitchell, Navajo Blessingway Singer, was in part "a realization of Frank's wish that a book on his life would live after him" as well as a sense of "family unity" growing out of his long years of collaboration with the editors.43 Editors Frisbie and McAllester acknowledge that their relationships with Frank Mitchell were intensely human ones that progressed from an initial development of rapport, through work on various projects, to lifelong friendships with mutual obligations and responsibilities.44 That this book is dedicated to the memory of Frank Mitchell is not coincidental.

\section{Mediating Tradition}

Navajo Blessingway Singer also leads us into a third mode of transmission-mediation. In addition to memorializing Frank Mitchell, Frisbie and McAllester mediate between him and the wider world: "Frank, of course, is the author of Navajo Blessingway Singer. Our job has been to collect the data, edit the narration and, with the assistance of able interpreters, put it into English." 45 In one sense, every time a scholar quotes or paraphrases an interview or conversation, he mediates tradition. Some ethnomusicologists and folklorists have in fact referred to themselves as mediators. Alan Lomax doesn't consider himself a "reviver so much as a stander-in-between," perceiving an important part of his responsibility to "find the best folk singers . . . and get them heard everywhere." ${ }^{6}$ Beth Lomax Hawes put it even more strongly in comments made at a 1981 Folk Arts Panel meeting: "That's right, we're meddlers!" 47

Mediation takes many forms and may not be restricted to an intermediary zone between the community and outsiders. In addition to "mediating" for my Syrian research associates, giving talks to introduce their performances to audiences unfamiliar with the pizmon repertory, I also was asked to assume this role within the community. At a gathering of the extended Tawil clan and a larger number of other Syrian families at a Catskill mountain resort one Passover in the late 1980 s, Moses Tawil arranged for me to give a public lecture on the SyrianJewish musical tradition; the majority of the audience at my talk was Syrian Jews. Mediation can therefore entail not just translating for

43 Charlotte J. Frisbie and David P. McAllester, eds., Navajo Blessingway Singer. The Autobiography of Frank Mitchell 1881-1967, (Tucson, 1978), 5 .

44 Frisbie and McAllester, Navajo Blessingway Singer, 5.

45 Frisbie and McAllester, Navajo Blessingway Singer, 8.

$4^{6}$ Cited in Sheehy, "A Few Notions," 329.

47 Cited in Jeff Todd Titon, "Music, the Public Interest, and the Practice of Ethnomusicology," Ethnomusicology XXXVI (1992), 316. 
those outside of the tradition, but participating in raising awareness of the tradition within the community itself. $4^{8}$

I suggest then, that many (if not all) ethnomusicologists preserve, memorialize, and mediate traditions on a fairly regular basis, in large part because of what I would term the "bracketed performativeness" of the materials they study. Both in the field and afterwards, this is emphatically not a theoretical issue. One learns music by doing and remembers by repeating, whether through live performance or sound recordings. Ethnomusicological data in the musical domain are replicable in a way in which other types of ethnographic data are emphatically not. I would propose, therefore, that the involvement of the ethnomusicologist in the transmission of tradition is an old and deep aspect of the ethnomusicological research process, emerging at once from a complicated intellectual history, from an idiosyncratic ethnographic method, and from the very nature of its data.

\section{Conclusions}

The ethnomusicologist's bifurcated identity, which draws at once upon musicological commitments to performance and anthropological tenets of non-interference, is reinforced during every encounter in the field. So deep is the tension between these approaches that one leading scholar wrote that the ethnomusicologist "does not seek the aesthetic experience for himself as a primary goal (though this may be a personal by-product of his studies), but rather he seeks to perceive the meaning of the aesthetic experience of others from the standpoint of understanding human behavior." 49 Only in more recent ethnomusicological publications are there explicit acknowledgments of the shared involvement that emerges in the field. In the words of one ethnographer:

There is no substitute in ethnomusicological fieldwork for intimacy born of shared musical experiences. Learning to sing, dance, play in the field is good fun and good method. Being an appreciative audience is an especially important form of musical exchange. Savour the joy of being a student again; establishing a close relationship with a master musician is a common and successful approach in ethnomusicology..$^{\circ}$

$4^{8}$ Repeated mediation of these different types also led to one of the most interesting acts of exchange in my academic career. In April 1991, Moses Tawil was invited to speak at the meeting of the Coalition for the Advancement of Jewish Education. He asked if he could borrow a copy of my Passover Catskill lecture along with the accompanying tape of musical examples to use for his talk, reassuring me that he would credit me at the beginning of the presentation. I sent him the materials he requested; he reported that the talk went well.

49 Alan P. Merriam, The Anthropology of Music (Evanston, 1964), 25.

5o Helen Myers, "Fieldwork," in Ethnomusicology. An Introduction (New York, 1992), 31. 
Likely there will be no single resolution of the ambivalent but active relationship of the ethnomusicologist to the tradition he studies. Indeed, disciplinary histories recede into the background once the scholar enters the field and encounters a new set of human and musical realities. In the end, the nature of any ethnomusicologist's activity will be determined by the dimensions of her contract with the carriers of the tradition itself, an interaction that at many points moves beyond a formal research process into the realm of deeply felt relationships.

Most ethnomusicologists are well aware that they do not study a disembodied concept called "culture" or a place called the "field," but rather encounter a stream of individuals to whom they are subsequently linked in new ways. Given the increasing interest in what anthropologist Arjun Appadurai has called "deterritoralization," I would suggest that human relations may be the most promising residue of a field once conceptualized as local, stable, and bounded. $5^{1}$ Within that context, the ethnomusicologist's role as transmitter of tradition may be more openly evaluated-and acknowledged.

Harvard University

${ }^{1}$ Arjun Appadurai, "Global Ethnoscapes: Notes and Queries for a Transnational Anthropology," in Recapturing Anthropology. Working in the Present, ed. Richard G. Fox, (Santa Fe, 1991), 192. 